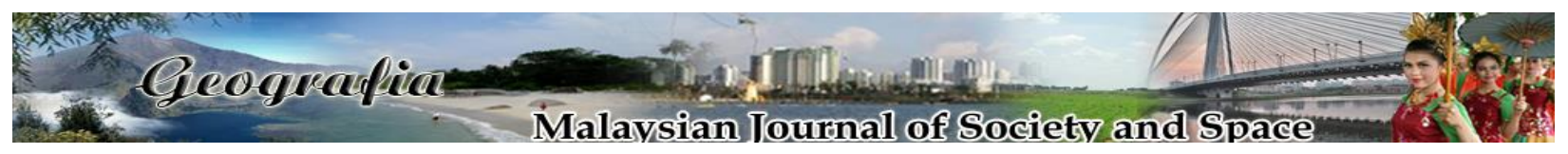

\title{
Impact of sprawl on the peri-urban areas
}

\author{
Daniel Nosakhare Onaiwu ${ }^{1}$, Faith Osagioduwa Onaiwu² \\ ${ }^{1}$ Department of Geography and Regional Planning, Faculty of Social Sciences, \\ University of Benin, Nigeria \\ ${ }^{2}$ Auchi Polytechnic, School of Environmental Studies, Department of Building Auchi, \\ Edo State, Nigeria
}

Correspondence: Daniel Nosakhare Onaiwu (email: Daniel.onaiwu@yahoo.com)

Received: 04 February 2019; Accepted: 22 March 2019; Published: 14 May 2019

\begin{abstract}
Urban sprawl is a major challenge on the spatial growth of settlements in the $21^{\text {st }}$ century. It is often confined to the peri-urban areas, and its impact on the social, economic, and environmental conditions of cities. The present study examined the impact of sprawl on the peri-urban areas of Benin City, Nigeria. It used a sample survey of 390 respondents that were selected in six suburban strata of road corridors radiating from the central business district (CBD) of Benin City. A sample size of 65 respondents was used in each stratum because of the sparse population. The instrument administered to the household heads was a likert-type. The data from the study were descriptively analysed, using frequencies and percentages. Analysis of variance was used to test the significance of the spatial variability of the impact between the strata. There was a significance difference between the six strata in the combined dependent variables. The results revealed indiscriminate dumping of solid waste, increased travel costs, high crime rate, increased cost of infrastructure, and land conversion as major impact on the peri-urban areas of Benin City. The impact of agricultural land conversion, solid waste and crime were significant. It was recommended that a master plan should be prepared for Benin City at a regional setting to segregate agricultural land from other urban land uses, the high crime in peri-urban areas should be checked by government and waste dumps should be properly sited.
\end{abstract}

Keywords: environment, impact, land conversion, peri-urban, sprawl, urban patch density

\section{Introduction}

The major urban challenge of the twenty-first century is the rapid spatial growth of many cities; and evidence around the world suggests that urban planning has failed to address it (Antrop, 2004; Ravetz et al., 2013; Paul \& Sharma, 2016). Urban sprawl and unplanned developments are among the most visible consequences of rapid and uncontrolled urban growth. One of the 
difficulties in understanding the impact of sprawl is that different observers have defined it by a combination of its causes, characteristics, and effects. Bartley and Treadwell (2003) noted that sprawl is an aesthetic judgment; as the cause of an externality (high automobile dependence); as a low density development pattern; and as a process of development through the passage of time. In most of the literature on sprawl, 'sprawl' has negative connotations and is attributed with environmental degradation, intensifying segregation, loss of the vitality of urban environment.

Urban sprawl mostly takes place at the peri-urban areas of the city. The peri-urban areas are zones that interface between the city and completely rural areas (Adell, 1999; McGregor et al., 2006). According to Ravetz et al. (2013) peri-urbanization is the dominant type of urbanization in the twenty-first century, which is transitional and multi-functional. They asserted that many urban challenges of environmental degradation, social and governance arise in cities.

Some scholars have quantitatively and graphically studied sprawl in order to evolve better approaches in understanding the impact of sprawl on the peri-urban areas (e.g. Solecka et al., 2017; Zhang et al., 2017). Solecka et al. (2017) used Space Index [SI] as a criterion for measuring sprawl in terms of discontinuous urban fabric. The change in discontinuous land cover from agriculture to other uses was dynamic. The result revealed that housing was the most dominant feature of land conversion, and followed by industrial and commercial uses respectively.

Urban sprawl has affected many fields of life (Burton, 2000). According to him, it affected the quality of life, environment, economy, and society in general. Over time as urban sprawl expanded, it became increasingly out of control, and the more negative effects it had on the whole society (Burton, 2000). Therefore, urban sprawl has become a matter of concern for residents not only because of the intensity of the process but also because of its great environmental, social and economic impacts. Also, sprawl leads to an increase in commuting distance due to the more scattered nature of urban areas, exacerbates traffic congestion and, in turn, air pollution (Cameron et al., 2004). Excessive land conversion to urban uses diminishes land and forest availability, which represents a loss of the amenity benefits from open space (Camagni et al., 2002).

Benin City has been affected by urban growth and associated spatial expansion over the years and this has serious implications on the surrounding areas (Uwadiae, 2017; Nkeki, 2018). It is important to understand how significant the impact of sprawl on peri-urban areas of Benin City are. There are a few researches that have addressed the urban sprawl in Benin City. Nkeki (2018) used the concept of 'Patch Density' to measure sprawl in Benin City. This revealed that density falls from the core, intermediate to the suburban areas of Benin City. Thus, this study seeks answers to the following questions: (a) what are the impact of urban sprawl on the periurban areas of Benin City; (b) what policies can be used to address urban sprawl in Benin City; and (c) how significant are the spatial variability of the impact of sprawl on the peri-urban areas of Benin City? The answers to these questions will reveal the implications of the impact of sprawl on the peri-urban areas of Benin City. 


\section{Literature review}

\section{Characteristics of peri-urban areas}

Sprawl in the peri-urban areas of settlements has assumed some worrisome dimension that is attracting scholars of settlement development both in the developed and less developed countries. Peri-urban areas are low-density areas often found in areas of mixed rural and urban population and land uses (Godha, 2018). He emphasized that the peri-urban areas alter the spatial structure of the city in both negative and positive ways. The peri-urban areas make natural environment accessible to urban users; however, its negative impact of unwholesome conversion of agricultural land to other uses and the destruction of fragile resources attract serious criticisms (Godha, 2018). There are often many challenges in terms of institutions, responsibilities, infrastructural provision, housing and heterogeneous populations noticeable in such areas (Jones, 2017). These challenges of unhealthy growth in the peri-urban and fringe areas of urban settlements were acknowledged as among the major drivers of unsustainable settlements of the 21st century. Next, the impact of sprawl on peri-urban areas are briefly covered in the following review.

\section{Conversion of agricultural land}

A major impact of peri-urbanization is the encroachment of urban land uses into peri-urban areas, that is, agricultural land that are close to urban areas. This phenomenon affects both developed and less developed cities (Sun et al., 2011; Ravi et al., 2016; Sanz et al., 2016; Wahab $\&$ Abiodun, 2018). Wahab and Abiodun (2018) viewed the peri-urban areas of Ibadan, Nigeria as a valuable land in strengthening food security because of the good soil, closeness to urban markets, the use of natural resources and waste, and the availability of water (p.57). They emphasized that peri-urban agriculture is germane in addressing food security. They, however, found that the sprawl is gradually making urban agriculture extinct because of agricultural land conversion to urban uses.

Sanz et al. (2016) described the sprawling activities which are of concern in the loss of farm land which needs to be legitimately protected by urban planning. They sought a way of integrating agriculture and urban planning into a singular territorial project such that rural and urban areas are no longer isolated bits, but a resilient model building on the two.

The model was tested based on two case studies - Madrid metropolitan area in Spain and Avignon urban area in France. Madrid is a compact urban development and Avignon is a lowdensity dispersed urban area. The study recommended that landscape planning management tools should be integrated into agricultural management in order to evolve adaptive territorial management. This integrative approach to urban growth process is worth considering in the study area (Sudhira et al., 2007; Torres, 2011).

\section{Peri-urban solid waste}

Managing urban solid waste has been a major challenge in many cities, especially in the periurban areas where some nonchalance is felt that they are the sinks that can absorb the waste from other parts of the city. Zurbrugg and Schertonleib (1998) reported that municipal waste can lead to full-scale crisis, if not properly managed. They stressed that the key elements in the waste 
management process are: waste collection, waste disposal, and waste prevention, reuse, recycling and recovery of valuable products. These elements are seldom carried out in less developed countries and the peri-urban areas are often derelict land, abandoned burrow pits only to be recovered with solid waste. Thus, there is the need for dumpsites and landfills to be properly designated to avoid the negative impact on public health of their lack (Shaw, 2005).

\section{Infrastructure in peri-urban areas}

The peri-urban areas of a city are usually of much distance from the core area of the city and this makes such places inaccessible to main infrastructural facilities. In Tianjin, China, Sun et al. (2011) described the nature of the difficulty in extending infrastructural services to the periurban areas. Thus, service infrastructure provision of water, electricity, sewage "lagged behind settlement planning and construction, accessibility to services and becomes the dominant factor in sustainable peri-urban settlements" (p.11).

Riveva (n.d.) also claimed that dwellers living at the rural-urban interface find it difficult to meet the cost of their water and sanitation needs because of low population density, which directly increases cost of public services; no formal plans and programmes are limited in such places; and sprawling that characterizes the rural urban interface (Allen, et al. 2006, cited in Rivera, n.d.). The peri-urban areas of less developed cities in Nigeria showed more of rural characteristics of infrastructural deficiency and providing them with infrastructure is bound to lead to huge cost.

\section{Peri-urbanization and commuting distance to activities}

Urbanization is also reflected in terms of the large spatial expansion in size which leads to increase in commuting distance to major land use activities. One major effect of periurbanization is that sprawl increases distance and separates activities and leads much to car dependence (Camagni et al., 2002). Camagni et al. (2002) argued that difficult land uses generate their pattern of urban mobility, especially work trips. They claimed that the trips generated at the sprawled areas are less. Since the morphology of the peri-urban areas is less organized and unstructured, there are bound to be more trips directed towards other areas of high population density and land use intensity (Camagni et al., 2002).

\section{Methods and study area}

Benin City is the capital and largest urban centre in Edo State. The city is located between latitude $6^{\circ} 14^{\prime} \mathrm{N}$ and $6^{\circ} 21^{\prime} \mathrm{N}$ of the equator and longitude $5^{\circ} 34^{\prime} \mathrm{E}$ and $5^{\circ} 44^{\prime} \mathrm{E}$ of the Greenwich Meridian (Nkeki, 2018). Benin City occupied initially three local government areas of Egor, Oredo and Ikpoba-Okha. However, with its rapid spatial expansion, it has expanded into the contiguous local government areas of Ovia North East, Uhunmwuode, and Orhionmwon. The total land area of the continuous urban form is $531 \mathrm{sq}$. km (Google Earth, 2015). Describing the phases of urban spatial expansion, Nkeki (2018) estimated the growth as follows:1938 it was 4.8 sq. km; 1952 it was 9.5 sq. km; 1964 it was 20 sq. km; 1972 it was 30 sq. km; 1982 it was 100 sq. km; 2001 it was 223 sq. km. The population of Benin City is 1,246,226 (National Population Commission, 2006). The high population is due to the influx of people from the surrounding 
rural areas as well as other parts of the country. The city is a primate settlement in Edo State with a hub of economic activities. Figure 1 is the map of the study area.

The study employed a survey whose population was projected from 1,242,226 (National Population Commission, 2006) in 2017 and increased to 1,719,531 at an urban growth rate of 3.0 percent. Using an error margin of 0.05, the sample size is 398 persons (Institute of Food and Agricultural Science [IFAS], 2009). Stratified random sampling was used to select the 390 samples that were retrieved. The six strata, which were road corridors, were each allocated 65 samples because of their sparse population. The survey was carried out at the suburban areas, that is, the areas traversed by the road corridors from the core to suburb (Figure 1).

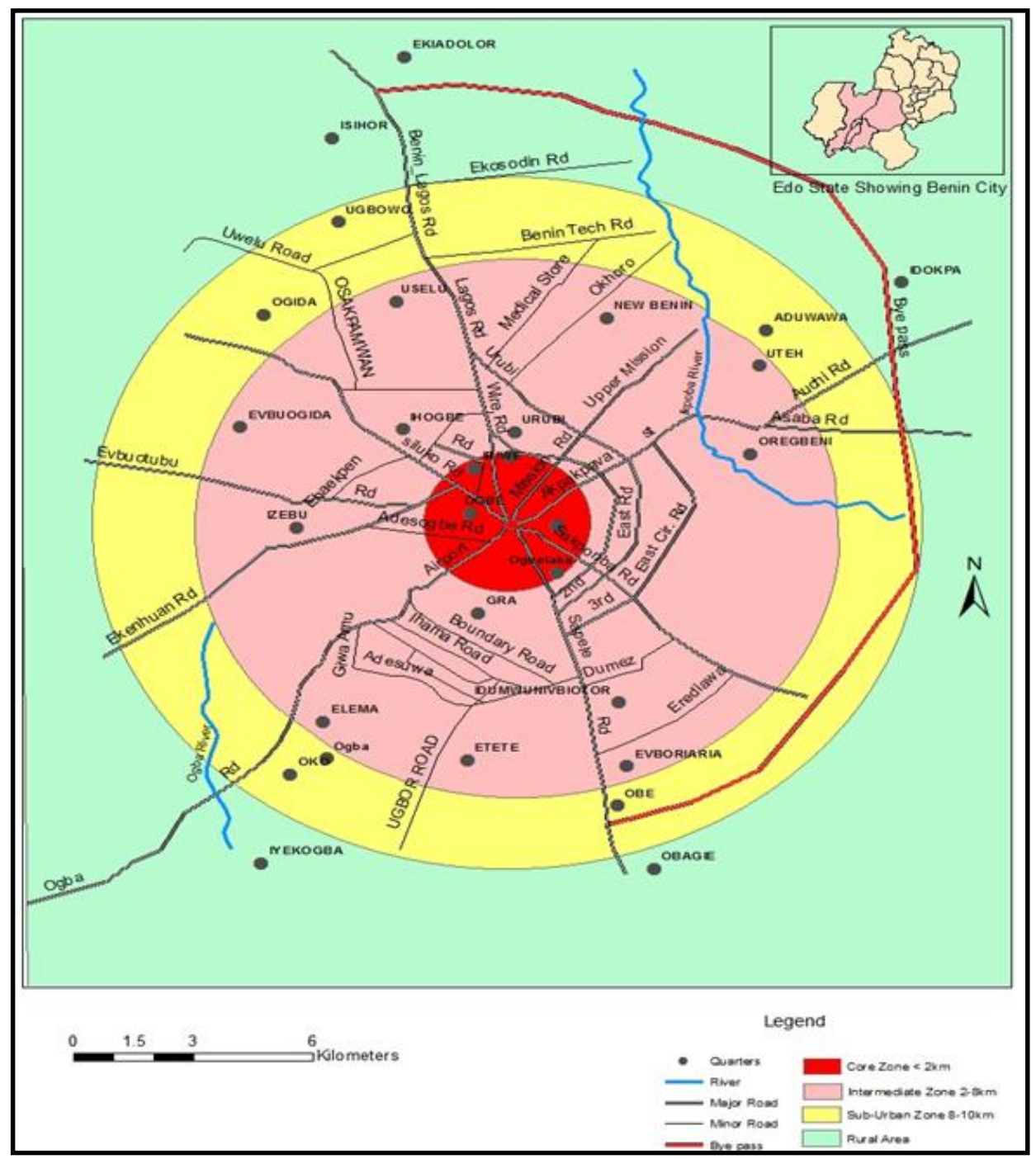

Source: Ministry of Lands Surveys and Housing (Modified by the Author), 2018.

Figure 1. Map of Benin City showing the peri-urban areas

The instrument for the survey was a structured questionnaire in the form of Likert-type scale of a five-point. The survey was administered on the heads of the households randomly because the houses where the respondents live in were of low density and of no characteristic pattern of 
arrangement. The survey instrument was pre-tested in a pilot survey before the main survey. Descriptive statistics of percentages and frequencies were used in describing the impact of urban sprawl on peri-urban areas of Benin City. Multivariate analysis of variance was used in determining the significance of the variability of the impact of sprawl on the peri-urban areas of Benin City. The reliability of the instrument was based on Conbach alpha coefficient of 0.6; and the validity was carried out by two senior colleagues of the Department of Geography, University of Benin, Benin City. The analysis of the data was done with the aid of SPSS Version 18.

\section{Results and discussion}

Indiscriminate dumping of solid waste in peri-urban areas

The peri-urban areas are sanctuaries for the dumping of solid waste. This results from the fact that there are no proper arrangements for the collection, transfer, and dumping of solid waste in the city. Table 1 shows the remarks of the respondents on indiscriminate dumping of solid wastes. The figures in brackets are in percentages in the tables. $\mathrm{S} / \mathrm{N}$ stands for serial number in a table.

Table 1. Indiscriminate dumping of solid waste

\begin{tabular}{lccccccc}
\hline $\begin{array}{l}\text { Extent of the } \\
\text { Degree }\end{array}$ & $\begin{array}{c}\text { Airport } \\
\text { Road }\end{array}$ & $\begin{array}{c}\text { Siluko } \\
\text { Road }\end{array}$ & $\begin{array}{c}\text { Ekenwan } \\
\text { Road }\end{array}$ & $\begin{array}{c}\text { Benin- } \\
\text { Lagos } \\
\text { Road }\end{array}$ & $\begin{array}{c}\text { Benin- } \\
\text { Sapele } \\
\text { Road }\end{array}$ & $\begin{array}{c}\text { Benin- } \\
\text { Agbor } \\
\text { Road }\end{array}$ & $\begin{array}{c}\text { Total/ } \\
\text { Percent }\end{array}$ \\
\hline Very little extent & $5(1.3)$ & $6(1.5)$ & $4(1.0)$ & $5(1.3)$ & $10(2.6)$ & $5(1.3)$ & $35(9-0)$ \\
Little extent & $16(4.1)$ & $10(2.6)$ & $9(2.3)$ & $3(0.7)$ & $4(1.0)$ & $5(1.3)$ & $47(12.0)$ \\
Moderate & $13(3.3)$ & $16(4.1)$ & $20(5.2)$ & $12(3.1)$ & $14(3.6)$ & $10(2.6)$ & $85(21.8)$ \\
Large extent & $25(6.4)$ & $26(6.7)$ & $30(7.7)$ & $41(10.5)$ & $28(7.2)$ & $40(10.3)$ & $190(48.7)$ \\
Very large extent & $6(1.5)$ & $7(1.8)$ & $2(0.5)$ & $4(1.0)$ & $9(2.3)$ & $5(1.3)$ & $33(8.5)$ \\
\hline
\end{tabular}

The indiscriminate dumping of solid waste affects much on the areas. On aggregate basis, 21.8 percent of the areas are moderately affected; 48.7 percent are to a large extent affected; and 8.5 percent are to a very large extent affected. Only about 22.0 percent of the peri-urban areas are less affected by this act of indiscriminate dumping of waste. The areas mostly affected to a large extent are Benin-Lagos Road (11.5\%), and Benin-Agbor Road (11.6\%); and the other areas are equally affected to a large extent. It is very clear from the responses that the peri-urban areas are eye sores because of the huge, unsightly deposition of solid waste in them. This is a major environmental degradation in the peri-urban land and many studies have confirmed this (Zurbrugg et al., 1998; Burton, 2000; Cameron et al., 2004).

\section{Loss of agricultural land in peri-urban areas}

A vital impact of interest to the Nigerian society is the loss of valuable agricultural land during a time of food insecurity. The peri-urban areas ought to be where agricultural activities can take place, but are now being invaded by uses that are non-agricultural. The respondents were asked to perceive the extent land is being lost to other land uses in peri-urban areas of Benin City due 
to sprawl. About 51.3 percent accepted that this emerging trend of loss of agricultural land is to a large extent (Table 2).

Table 2. Loss of agricultural land

\begin{tabular}{lccccccc}
\hline $\begin{array}{l}\text { Extent of the } \\
\text { Degree }\end{array}$ & $\begin{array}{c}\text { Airport } \\
\text { Road }\end{array}$ & $\begin{array}{c}\text { Siluko } \\
\text { Road }\end{array}$ & Ekenwan & $\begin{array}{c}\text { Benin- } \\
\text { Lagos }\end{array}$ & $\begin{array}{c}\text { Benin- } \\
\text { Sapele }\end{array}$ & $\begin{array}{c}\text { Benin- } \\
\text { Agbor }\end{array}$ & $\begin{array}{c}\text { Total/ } \\
\text { Percent }\end{array}$ \\
\hline Very little extent & $6(1.5)$ & $10(2.6)$ & $2(0.5)$ & $8(2.1)$ & $14(3.6)$ & $18(4.6)$ & $58(14.9)$ \\
Little extent & $7(1.8)$ & $6(1.5)$ & $4(1.0)$ & $3(0.7)$ & $3(0.7)$ & $2(0.5)$ & $25(6.4)$ \\
Moderate & $20(5.1)$ & $18(4.6)$ & $18(4.6)$ & $16(4.1)$ & $5(1.3)$ & $4(1.0)$ & $81(20.8)$ \\
Large extent & $12(3.1)$ & $14(3.6)$ & $16(4.1)$ & $14(3.6)$ & $16(4.1)$ & $18(4.6)$ & $90(23.1)$ \\
Very large extent & $15(3.8)$ & $14(3.6)$ & $19(4.8)$ & $20(5.1)$ & $21(5.4)$ & $21(5.4)$ & $110(28.2)$ \\
Not indicated & $5(1.3)$ & $3(0.7)$ & $6(1.5)$ & $4(1.0)$ & $6(1.5)$ & $2(0.5)$ & $26(6.7)$ \\
\hline
\end{tabular}

About $20.8 \%$ claimed that this trend is moderate; and about $21.3 \%$ said that the loss of agricultural land is of little extent; and 6.7 percent did not respond to this. Benin-Sapele Road $(6.9 \%)$ is most affected by loss of agricultural land, and followed by Ekenwan Road (6.3\%). There is the need to check this valuable loss of agricultural resource if Nigeria is to make appreciable impact in increasing agricultural productivity. The loss of agricultural land is a serious problem in both developed and less developed countries (Sudhira et al., 2007; Dadi et al., 2016; Solecka et al., 2017; Zhang et al., 2017). These researchers suggested different approaches in protecting peri-urban agricultural land from encroachment by other uses.

\section{Increased cost of travel in peri-urban areas}

Urban residents make a lot of trips to other areas where employment, commercial, recreational and other land use activities are sited. Thus, the residents in the sprawl areas will of necessity travel especially to the core areas of Benin City where these activities are concentrated. These trips will definitely increase their expenditure on travel. Table 3 indicates responses on travel cost.

Table 3. Increased cost of travel

\begin{tabular}{lccccccc}
\hline Extent of the degree & $\begin{array}{c}\text { Airport } \\
\text { Road }\end{array}$ & $\begin{array}{c}\text { Siluko } \\
\text { Road }\end{array}$ & Ekenwan & $\begin{array}{c}\text { Benin- } \\
\text { Lagos }\end{array}$ & $\begin{array}{c}\text { Benin- } \\
\text { Sapele }\end{array}$ & $\begin{array}{c}\text { Benin- } \\
\text { Agbor }\end{array}$ & $\begin{array}{c}\text { Total/ } \\
\text { Percent }\end{array}$ \\
\hline Very little extent & $10(2.6)$ & $9(2.3)$ & $8(2.1)$ & $6(1.5)$ & $5(1.3)$ & $4(1.0)$ & $42(10.77)$ \\
Little extent & $13(3.3)$ & $12(3.1)$ & $6(1.5)$ & $10(2.6)$ & $17(4.4)$ & $7(1.8)$ & $65(16.7)$ \\
Moderate & $12(3.1)$ & $12(3.1)$ & $7(1.8)$ & $4(1.0)$ & $10(2.6)$ & $14(3.6)$ & $59(15.1)$ \\
Large extent & $20(5.1)$ & $20(5.1)$ & $30(7.7)$ & $35(9.0)$ & $18(4.6)$ & $27(6.9)$ & $150(38.5)$ \\
Very large extent & $10(2.6)$ & $12(3.1)$ & $14(3.6)$ & $10(2.6)$ & $15(3.8)$ & $13(3.3)$ & $74(19.0)$ \\
\hline
\end{tabular}

Most respondents asserted that their travel costs increase as a result of the trips they make to other parts of Benin City. As much as 53.6 percent said that their travel costs are increased as a result of trips to other areas; 15.1 percent claimed that their travel costs are moderate. The residents of Benin-Lagos Road (11.6\%), and Ekenwan (11.3\%) experienced the highest travel costs in the peri-urban areas of the city. Thus, sprawl has the tendency of disproportionate travel costs to urban land uses where it occurs. This amounts to a negative impact on peri-urban residents. It was revealed in the study that cost of travel of residents that live in peri-urban areas of Benin City has increased especially trying to access facilities in the core areas of Benin City. 
The people living in the peri-urban areas demand certain higher-ordered goods and services that are presently not found in where they live. This increased travel cost is a serious problem in some Western studies whereby people will have to move considerable distances before they can access some goods and services they desired.

This phenomenon has started in cities of developing countries where sprawl has emerged. Thus, this feature has been confirmed by many Most respondents asserted that their travel costs increase as a result of the trips they make to other parts of Benin City. As much as 53.6 percent said that their travel costs are increased as a result of trips to other areas; 15.1 percent claimed that their travel costs are moderate. The residents of Benin-Lagos Road (11.6\%), and Ekenwan (11.3\%) experienced the highest travel costs in the peri-urban areas of the city. Thus, sprawl has the tendency of disproportionate travel costs to urban land uses where it occurs. This amounts to a negative impact on peri-urban residents. It was revealed in the study that cost of travel of residents that live in peri-urban areas of Benin City has increased especially trying to access facilities in the core areas of Benin City. The people living in the peri-urban areas demand certain higher-ordered goods and services that are presently not found in where they live. This increased travel cost is a serious problem in some Western studies whereby people will have to move considerable distances before they can access some goods and services they desired. This phenomenon has started in cities of developing countries where sprawl has emerged. Thus, this feature has been confirmed by many studies in developed countries because of the variegation of activities in sprawl areas (Borrego et al., 2006). This pattern has started manifesting in Benin City because of its mono-centric CBD structure that makes the core attractive to residents.

\section{Level of crime at the peri-urban areas}

Urban residents in Nigeria are conscious of the high level of crime in where they live in. The level of crime impacts greatly on the spatial wellbeing of a community and has become a notable indicator of the livability of a place. The impact of crime at the peri-urban areas is indicated in Table 4.

Table 4. Level of crime at the peri-urban areas

\begin{tabular}{lccccccc}
\hline Extent of the degree & $\begin{array}{c}\text { Airport } \\
\text { Road }\end{array}$ & $\begin{array}{c}\text { Siluko } \\
\text { Road }\end{array}$ & $\begin{array}{c}\text { Ekenwan } \\
\text { Road }\end{array}$ & $\begin{array}{c}\text { Benin- } \\
\text { Lagos } \\
\text { Road }\end{array}$ & $\begin{array}{c}\text { Benin- } \\
\text { Sapele } \\
\text { Road }\end{array}$ & $\begin{array}{c}\text { Benin- } \\
\text { Agbor } \\
\text { Road }\end{array}$ & $\begin{array}{c}\text { Total/ } \\
\text { Percent }\end{array}$ \\
\hline Very little extent & $1(0.3)$ & $2(0.5)$ & $1(0.3)$ & - & $1(0.3)$ & $1(0.3)$ & $6(1.5)$ \\
Little extent & $15(3.8)$ & $5(1.3)$ & $3(0.8)$ & $4(1.0)$ & $6(1.5)$ & $7(1.8)$ & $40(10.3)$ \\
Moderate & $3(0.8)$ & $2(0.5)$ & $7(1.8)$ & $6(1.5)$ & $2(0.5)$ & $2(0.5)$ & $22(5.6)$ \\
Large extent & $21(5.4)$ & $28(7.2)$ & $19(4.9)$ & $22(5.9)$ & $29(7.4)$ & $31(7.9)$ & $151(38.7)$ \\
Very large extent & $25(6.4)$ & $28(7.2)$ & $35(9.0)$ & $32(8.2)$ & $27(6.9)$ & $24(6.2)$ & $171(43.8)$ \\
\hline
\end{tabular}

On aggregate basis, 82.5 percent of the respondents claimed that the crime level is to a large extent high at the peri-urban areas. About 11.8 percent said that the crime rate is to a little extent. Generally high crime rate exists in the six axial roads of the study (see Table 4). The peri-urban areas are hideouts for criminals to carry out their activities. These places need to be secured so that urban residents can enjoy some level of peace. This aspect of crime in peri-urbanization has not received much attention in the literature because of the relatively recent high level of urbanization in Nigeria. 


\section{Cost of electrical infrastructure at the peri-urban areas}

The provision of infrastructure is an essential service in an urban development. An important infrastructure in urban environment is the provision and use of electricity. The respondents were asked to assess the cost of electricity supply in the peri-urban areas and their responses are shown in Table 5.

Table 5. Cost of electrical infrastructure

\begin{tabular}{lccccccc}
\hline Extent of the degree & $\begin{array}{c}\text { Airport } \\
\text { Road }\end{array}$ & $\begin{array}{c}\text { Siluko } \\
\text { Road }\end{array}$ & Ekenwan & $\begin{array}{c}\text { Benin- } \\
\text { Lagos }\end{array}$ & $\begin{array}{c}\text { Benin- } \\
\text { Sapele }\end{array}$ & $\begin{array}{c}\text { Benin- } \\
\text { Agbor }\end{array}$ & $\begin{array}{c}\text { Total/ } \\
\text { Percent }\end{array}$ \\
\hline Very little extent & $4(1.0)$ & $2(0.5)$ & $5(1.3)$ & $3(0.8)$ & $2(0.5)$ & $4(1.0)$ & $20(5.1)$ \\
Little extent & $6(1.5)$ & $5(1.3)$ & $5(1.3)$ & $7(1.8)$ & $4(1.0)$ & $5(1.3)$ & $32(8.2)$ \\
Moderate & $22(5.6)$ & $25(6.4)$ & $18(4.6)$ & $27(6.9)$ & $20(5.1)$ & $8(4.6)$ & $120(30.8)$ \\
Large extent & $22(5.6)$ & $25(6.4)$ & $14(3.6)$ & $16(4.1)$ & $28(7.2)$ & $31(7.9)$ & $136(34.9)$ \\
Very large extent & $11(2.8)$ & $8(2.1)$ & $23(5.9)$ & $12(3.1)$ & $11(2.8)$ & $17(4.4)$ & $82(21.0)$ \\
\hline
\end{tabular}

To a little extent about 13.3 percent said that the cost of electricity is low; 30.8 percent claimed that the cost is moderate; and 55.9 percent saw the cost as much to a large extent. The cost of installation of electrical infrastructure is of highest extent at Benin-Agbor Road and least in Airport Road axis. The cost being determined is based on its linearity (i.e., cost of laying cables and connecting houses). Thus, sprawling of activities leads to increase in linear cost of electricity installation. Urban sprawl has negative impact in the cost of infrastructure of electricity in the peri-urban areas of Benin City. This high cost of infrastructure is as a result of scattered developments that raise average cost per unit of property. This inflated infrastructure and public service costs of sprawled areas were confirmed by Borrego et al. (2006) and Sun et al. (2011) in their studies respectively.

\section{Multivariate analysis of impacts of sprawl in the peri-urban areas of Benin City}

The impact of sprawl in the peri-urban areas of Benin City is the thrust of this study and it is necessary to carry out the test of significance in order to confirm if there is any variability amongst the strata. The statistic used is the multivariate analysis of variance (MANOVA) in which two or more groups (strata) were compared in terms of their dependent variables. Thus the null hypothesis is that the population means on a set of dependent variables do not vary across different levels of a factor or grouping variable (Pallant, 2011). The categorical variable for the test are the strata which is the independent variable; and the four dependent variables that measure impact of sprawl on peri-urban areas which are solid wastes, infrastructure cost, loss of agricultural land and crime rate. The assumptions of the MANOVA test are based on sample size, normality, outliers, linearity, homogeneity of regression, multi-collinearity and singularity, and homogeneity of variance-covariance matrices (Pallant, 2011). These assumptions were fairly complied with in the data tested. The employment of a large sample of 390 makes compliance fairly attainable.

The result of the one-way between-groups multivariate analysis of variance that was performed (Tables $6 \& 7$ ) is as follows: 
Table 6. Multivariate tests (Abridged)

\begin{tabular}{llccccc}
\hline Effect & Value & F & $\begin{array}{c}\text { Hypothesis } \\
\text { df }\end{array}$ & Error df & Sig. \\
\hline Intercept & Pillai's trace & .994 & $14693.017^{\mathrm{b}}$ & 4.000 & 376.000 & .000 \\
& Wilks' lambda & .006 & $14693.017^{\mathrm{b}}$ & 4.000 & 376.000 & .000 \\
& Hotelling's trace & 156.309 & $14693.017^{\mathrm{b}}$ & 4.000 & 376.000 & .000 \\
& Roy's largest root & 156.309 & $14693.017^{\mathrm{b}}$ & 4.000 & 376.000 & .000 \\
$\mathrm{q} 5$ & Pillai's trace & .818 & 19.472 & 20.000 & 1516.000 & .000 \\
& Wilks' lambda & .373 & 21.624 & 20.000 & 1248.001 & .000 \\
& Hotelling's trace & 1.218 & 22.803 & 20.000 & 1498.000 & .000 \\
& Roy's largest root & .704 & $53.367^{\mathrm{c}}$ & 5.000 & 379.000 & .000 \\
\hline
\end{tabular}

\begin{tabular}{llc}
\hline & \multicolumn{2}{c}{ Multivariate tests $^{\mathbf{a}}$} \\
\hline Effect & & Partial Eta Squared \\
Intercept & Pillai's trace & .994 \\
& Wilks' lambda & .994 \\
& Hotelling's trace & .994 \\
q5 & Roy's largest root & .994 \\
& Pillai's trace & .204 \\
& Wilks' lambda & .219 \\
& Hotelling's trace & .233 \\
\hline
\end{tabular}

Note:

a. Design: Intercept + q5

b. Exact statistic

c. The statistic is an upper bound on $\mathrm{F}$ that yields a lower bound on the significance level.

The independent variable are the strata, which are six; and the dependent variables are solid waste, infrastructural cost, loss of agricultural land, and crime rate. The preliminary assumption testing that was conducted to check for normality, linearity, univariate and multivariate outliners, homogeneity of variance - covariance matrices, and multi collinearity showed that there were no serious violations in the assumptions. There was a statistically significant difference among the six strata of the study on the combined dependent variables, $F(4,390)=21.624, \mathrm{p}=0.001$ Wilks' Lambda $=.994$; partial eta squared $=.219$ (see Table 6 Multivariate Tests Abridged). When the results for the dependent variables were considered separately, all the four dependent variables were statistically significant based on Bonferroni adjusted alpha level of $0.0125(0.05 \div 4)$. In terms of their partial eta squared, solid waste is .316 (31\%), infrastructure cost is .265(26\%), loss of agricultural land is $.229(22 \%)$, and crime rate is .163 (16\%) (see Table 7 Between Subject Effects, Abridged).

Table 7. Between subject effects, abridged

\begin{tabular}{|c|c|c|c|c|c|c|c|}
\hline Source & Dependent Variable & $\begin{array}{l}\text { Type III } \\
\text { Sum of } \\
\text { squares }\end{array}$ & $\overline{\text { Df }}$ & $\begin{array}{c}\text { Mean } \\
\text { square }\end{array}$ & $\mathbf{F}$ & Sig. & $\begin{array}{l}\text { Partial } \\
\text { eta } \\
\text { squared }\end{array}$ \\
\hline \multirow[t]{3}{*}{$\begin{array}{l}\text { Corrected } \\
\text { Model }\end{array}$} & $\begin{array}{l}\text { Solid wastes in } \\
\text { sprawl areas are } \\
\text { indiscriminately } \\
\text { disposed in open } \\
\text { dumpsite }\end{array}$ & $33.184^{\mathrm{a}}$ & 5 & 6.637 & 35.039 & .000 & .316 \\
\hline & Infrastructural costs & $47.898^{\mathrm{b}}$ & 5 & 9.580 & 27.360 & .000 & .265 \\
\hline & loss of agricultural & $99.649^{c}$ & 5 & 19.930 & 22.468 & .000 & .229 \\
\hline
\end{tabular}




\begin{tabular}{|c|c|c|c|c|c|c|c|}
\hline & land & & & & & & \\
\hline & Crime rates & $65.270^{\mathrm{d}}$ & 5 & 13.054 & 14.770 & .000 & .163 \\
\hline \multirow[t]{4}{*}{ Intercept } & $\begin{array}{l}\text { Solid wastes in } \\
\text { sprawl areas are } \\
\text { indiscriminately } \\
\text { disposed in open } \\
\text { dumpsite }\end{array}$ & 5799.244 & 1 & 5799.244 & 30617.048 & .000 & .988 \\
\hline & Infrastructural costs & 8114.491 & 1 & 8114.491 & 23175.558 & .000 & .984 \\
\hline & $\begin{array}{l}\text { Loss of agricultural } \\
\text { land }\end{array}$ & 7522.576 & 1 & 7522.576 & 8480.634 & .000 & .957 \\
\hline & Crime rates & 6570.270 & 1 & 6570.270 & 7433.811 & .000 & .951 \\
\hline \multirow[t]{4}{*}{ q5 } & $\begin{array}{l}\text { Solid wastes in } \\
\text { sprawl areas are } \\
\text { indiscriminately } \\
\text { disposed in open } \\
\text { dumpsite }\end{array}$ & 33.184 & 5 & 6.637 & 35.039 & .000 & .316 \\
\hline & Infrastructural costs & 47.898 & 5 & 9.580 & 27.360 & .000 & .265 \\
\hline & $\begin{array}{l}\text { loss of agricultural } \\
\text { land }\end{array}$ & 99.649 & 5 & 19.930 & 22.468 & .000 & .229 \\
\hline & Crime rates & 65.270 & 5 & 13.054 & 14.770 & .000 & .163 \\
\hline \multirow[t]{4}{*}{$\begin{array}{l}\text { Corrected } \\
\text { Total }\end{array}$} & $\begin{array}{l}\text { Solid wastes in } \\
\text { sprawl areas are } \\
\text { indiscriminately } \\
\text { disposed in open } \\
\text { dumpsite }\end{array}$ & 104.971 & 384 & & & & \\
\hline & Infrastructural costs & 180.597 & 384 & & & & \\
\hline & $\begin{array}{l}\text { Loss of agricultural } \\
\text { land }\end{array}$ & 435.834 & 384 & & & & \\
\hline & Crime rates & 400.244 & 384 & & & & \\
\hline
\end{tabular}

\footnotetext{
Note:

a. $\mathrm{R}$ Squared $=.316$ (Adjusted $\mathrm{R}$ squared $=.307)$

b. $\mathrm{R}$ Squared $=.265$ (Adjusted R squared $=.256$ )

c. $\mathrm{R}$ Squared $=.229$ (Adjusted $\mathrm{R}$ squared $=.218$ )

d. $\mathrm{R}$ Squared $=.163$ (Adjusted R squared $=.152$ )
}

Thus, all the dependent variables used as indicators in the test to show impacts of sprawl on peri-urban areas of Benin City were statistically significant both at combined and separate levels of the impacts in their variability. (i.e., the impact indicators varied between the strata and among themselves in effects; and they also varied separately from one stratum to another. The magnitude of these impacts are also substantially high using Colen's $d$ standard or cut-off point of eta squared 0.14 higher as high significance. The eta squared is the explained variance of the impact among the various strata of the study.

\section{Conclusions}

The following conclusions have been reached and recommendations have been suggested in addressing the negative impacts of sprawl in the peri-urban areas of Benin City. Presently, Benin City has not adopted any master plan for land use and planning related activities. Thus, periurban land use is erratic. Future master plan of the city should be prepared at its regional context to go beyond the corporate or compact built-up areas of Benin City. This act will allow for such areas to be regulated and subject to land use planning. Thus any obnoxious use of such areas should be sanctioned by law. 
There are no clear-cut schemes for managing solid waste in the study area. Edo State Government should have policies towards waste management, especially as regards the evacuation and disposal of solid wastes. There should be scientific methods of disposing solid waste through sanitary land fill and controlled incineration because of the role played by waste in hampering public health. Not until government does something positive by indicating how and where waste are to be disposed, the environmental challenge of waste management will continue to negatively impact the peri-urban areas of Benin City.

The peri-urban areas have more of rural than urban characteristics. These fertile lands ought to be devoted for agricultural purpose, but with the intrusion of urban activities the areas are losing fast their potentials. If Nigeria is to progress in her determination to provide food for her citizens, these fertile land should be put into productive agricultural use. In the developed countries urban agriculture has taken its foothold and there is the need for Nigeria to borrow this practice. This can best be achieved by carrying a study on soil feasibility survey for various crops to determine the suitability of various soils for the cultivation of different crops.

The peri-urban areas are growing areas for the different types of crime in Benin City. These crimes affect the sustainability of urban environment in terms of economic viability and security of lives and properties. The sprawl areas are hideouts for different armed gangs which the government must check to remove the fears of urban inhabitants. Thus there is the need to provide more security outfits to check the acts of barbarism going on in these places.

\section{References}

Adell, G. (1999). Theories and models of the peri-urban interface: A changing conceptual landscape strategic environmental planning and management for the peri-urban interface research project. London, Development Planning Unit, University College, London.

Allen, A., Dávila, J., \& Hoffman, P. (2006). The peri-urban water poor: citizens or consumers? Environment and Urbanization, 18(2), 333-351.

Antrop, M. (2004). Landscape change and urbanization process in Europe. Landscape and Urban Planning, 67(1-4), 9-26.

Bartley, B., \& Treadwell, S.K. (2003). Competitive city: Governance and the changing dynamics of urban regeneration in Dublin. In Moulaert, F., Rodriguez, A., \& Swyngedouw, E. (Eds.), The globalization city, economic restructuring and polarization in European cities (pp.145166). Oxford, Oxford University Press.

Borrego, C., Martins, H., Tchepel, O., Salmim, L., Monteiro, A. \& Miranda, A. I. (2006). How urban structure can affect city sustainability from an air quality perspective. Environmental Modelling and Software, 21(4):461-467. DOI: 10.1016/j.envsoft.2004.07.009

Burton, E. (2000). The compact city: Just of just compact? A preliminary analysis. Urban Studies, 37(11), 1969-2001. http://dx.doi.org/10.1080/00420980050162184

Camagni, R., Gibelli, M.C., \& Rigamonti, P. (2002). Urban mobility and urban form: The social and environmental costs of different patterns of urban expansion. Ecological Economies, 40(2), 199-216.

Cameron, I., Lyons T.J., \& Kenworthy, J.R. (2004). Trends in vehicle kilometers of travel in world cities, 1960-1990: Underlying drivers and policy responses. Transport Policy, 11(3), 287-298. 
Dadi, D., Azadi, H., Senbeta, F., Abebe, K., Taheri, F., \&, Stellmacher, T. (2016). Urban sprawl and its impacts on land use change in Central Ethiopia. Urban Forestry \& Urban Green, 16, 132-141. http://dx.doi.org/10.10.16/j.fug.2016.005

Godha, K.R. (2018). Land and infrastructure development in peri-urban areas: Case study of Gomti Nagar, Lucknow, India. http//dx.doi.org/10.5772/intechopen.73525.

Google Earth (2015). Satellite image of Benin Region. Retrieved from https://earth.google.com/web/

IFAS. (2008).Determining sample size. University of Florida, Institute of Food and Agricultural Sciences. Retrieved from http://edis.ifas.ufl.edu.

Jones, P. (2017). Formalizing the informal: Understanding the position of informal settlements and slums in sustainable urbanization policies and strategies in Bandwig, Indonesia. Sustainability, 9(1436), 4-27. http://dx.doi.org/10.3390/su9081439

McGregor, D., Simon, D., \& Thompson, D. (2006). The peri-urban interface: Approaches to sustainable environment. London, Earthscan.

National Population Commission (2006). 2006 National Population and Housing Census. Abuja, Federal Government of Nigeria.

Nkeki, F.N. (2018). The influence of built environment, socio-economic, demographic attributes on travel behaviour in Benin Metropolitan Region ( $\mathrm{PhD}$ dissertation). Department of Geography and Regional Planning, University of Benin, Benin City, Nigeria.

Pallant, J. (2011). SPSS survival manual: A step by step guide to data analysis using SPSS (4 ${ }^{\text {th }}$ ed.). Crows Nest, Australia, Allen \& Unwin.

Paul, K., \& Sharma, D. (2016). Post facto, trends, pattern of urbanity in Sikkim. Geografia: Malaysian Journal of Society and Space, 12(13), 13-29.

Ravetz, J., Fertner, C., \& Nielsen, T.S. (2013). The dynamics of peri-urbanization. In Nilson, K. et al. (Eds.). Peri-urban futures: Scenarios and models for land use change in Europe (pp. 13-44). http//dx.doi.org/10.1007/978-3-643-30528-4

Ravi, K.N., Ponnusamy, K., Kale, R.B., \& Mandal, P.L. (2016). Impact of urbanization on periurban farmlands of farmers in the Bagaluru metropolitan region, India. International Journal of Agriculture Science, 8(52), 2591-2594.

Rivera, N.R. (n.d.) Territorial planning of Mexico's rural-urban interfaces: A review of its characteristics, scales, problems and legal instruments. Departmento de Geografia, Social, Instituto de Geografia, Universidad Nacional Autonoma de Mexico (UNAM) Ciudad de Mexico, Distrito, Federal, Mexico.

Sanz, S.E., Napoleone, C., \& Huber, B. (2016). Peri-urban farmland characterization: A methodological proposal for urban planning. T\&F Sustainable Urban Agriculture and Food Planning.

Shaw, A. (2005). peri-urban interface of Indian Cities: Growth, governance and local initiatives. Retrieved from http://www.indiaevonmentportal.org.

Solecka, I., Sylla, M., \& Swiader, M. (2017). Urban sprawl impact on farmland conversion in suburban area of Wroclaw, Poland. Materials Science and Engineering, 245(21),1-10. http://dx.doi.org/10.1088/1757-899x/245/7/072002

Sudhira, H.S., Ramachandra, T.V., \& Subrahmanya, M.H.B. (2007). Urban sprawl management: Need for integrated spatial planning support system. Retrieved from httpp:// wgbis.ces.iisc.ernet.inbiodiversity/pubs/cestr/TR119 HSS Urban Sprawl. 
Sun, L., Gwilliam, J., \& Jones, P. (2011). Challenges to sustainable peri-urban settlement development in China: An analysis by empirical evidence in Tianjiu. WIT Transactions on Ecology and The Environment, 167, 1-2. http://dx.doi.org/10.2495/ST110011.

Torres, H.G. (2011). Environmental implications of peri-urban sprawl and the urbanization of secondary cities in Latin America. Inter-American Bank, Environmental Safeguard Unit Technical Notes No. 1DB-TN-237.

Uwadiae, O. (2017). The Impacts of sprawl on the peri-urban areas of Benin City (Master dissertation). Department of Geography and Regional Planning, University of Benin, Benin City, Nigeria.

Wahab, B., \& Abiodun, O. (2018). Strengthening food security through peri-urban agriculture in Ibadan, Nigeria. Ghana Journal of Geography, 10(2), 50-60. https://dx.doi.org/10.4314/gig.v10i2.4

Zhang, Z., Xiao, B., Weixuan, Y., Liu, M. \&, Wang, M. (2017). Characterizing factors associated with built-up land expansion in urban and non-urban areas from a morphological perspective. Sustainability, 9(1), 4-11. https://dx.doi.org/10.3390/su9081411

Zurbrugg, C., \& Scherteelieb, R. (1998). Main problems and issues of municipal solid waste management in developing countries with emphasis on problems related to disposal by landfill. Third Swedish Landfill Research Symposia. October. 